\title{
Front Matter: Volume 11740
}

, "Front Matter: Volume 11740," Proc. SPIE 11740, Infrared Imaging Systems: Design, Analysis, Modeling, and Testing XXXII, 1174001 (5 May 2021); doi: $10.1117 / 12.2598626$

SPIE. Event: SPIE Defense + Commercial Sensing, 2021, Online Only 


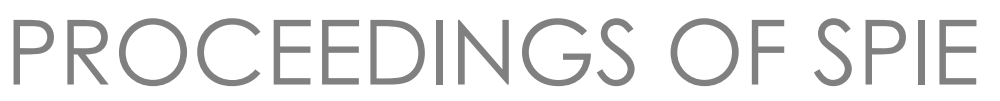

\title{
Infrared Imaging Systems: Design, Analysis, Modeling, and Testing XXXII
}

\author{
Gerald C. Holst \\ David P. Haefner \\ Editors
}

12-16 April 2021

Online Only, United States

Sponsored and Published by

SPIE 
The papers in this volume were part of the technical conference cited on the cover and title page. Papers were selected and subject to review by the editors and conference program committee. Some conference presentations may not be available for publication. Additional papers and presentation recordings may be available online in the SPIE Digital Library at SPIEDigitalLibrary.org.

The papers reflect the work and thoughts of the authors and are published herein as submitted. The publisher is not responsible for the validity of the information or for any outcomes resulting from reliance thereon.

Please use the following format to cite material from these proceedings:

Author(s), "Title of Paper," in Infrared Imaging Systems: Design, Analysis, Modeling, and Testing XXXII, edited by Gerald C. Holst, David P. Haefner, Proc. of SPIE 11740, Seven-digit Article CID Number (DD/MM/YYYY); (DOI URL).

ISSN: 0277-786X

ISSN: 1996-756X (electronic)

ISBN: 9781510643178

ISBN: 9781510643185 (electronic)

Published by

SPIE

P.O. Box 10, Bellingham, Washington 98227-0010 USA

Telephone +1 3606763290 (Pacific Time)

SPIE.org

Copyright (C) 2021 Society of Photo-Optical Instrumentation Engineers (SPIE).

Copying of material in this book for internal or personal use, or for the internal or personal use of specific clients, beyond the fair use provisions granted by the U.S. Copyright Law is authorized by SPIE subject to payment of fees. To obtain permission to use and share articles in this volume, visit Copyright Clearance Center at copyright.com. Other copying for republication, resale, advertising or promotion, or any form of systematic or multiple reproduction of any material in this book is prohibited except with permission in writing from the publisher.

Printed in the United States of America by Curran Associates, Inc., under license from SPIE.

Publication of record for individual papers is online in the SPIE Digital Library.

\section{SP|E. DIGITAL}

Paper Numbering: A unique citation identifier (CID) number is assigned to each article in the Proceedings of SPIE at the time of publication. Utilization of CIDs allows articles to be fully citable as soon as they are published online, and connects the same identifier to all online and print versions of the publication. SPIE uses a seven-digit CID article numbering system structured as follows:

- The first five digits correspond to the SPIE volume number.

- The last two digits indicate publication order within the volume using a Base 36 numbering system employing both numerals and letters. These two-number sets start with 00, 01, 02, 03, 04, 05, 06, 07, 08, 09, 0A, OB ... 0Z, followed by 10-1Z, 20-2Z, etc. The CID Number appears on each page of the manuscript. 


\title{
Contents
}

\author{
INTRODUCTION
}

$1174004 \quad$ High throughput thermal camera characterization (Invited Paper) [11740-3]

SYSTEMS

1174005 High performance cooled LWIR imager optics for optronics mast systems [1 1740-4]

1174006 Digital readout integrated circuit for high dynamic range infrared imaging [11740-5]

TESTING

11740 OA Performance characterization of low light level color imaging sensors [11740-9]

MODELING

$11740 \mathrm{OE} \quad$ Fast signature preserving LWIR detail uncovering and image enhancement with dedicated color tables [11740-13]

11740 OF Analytical solution for Gaussian pulse in RC circuit [1 1740-14]

11740 OG Deep echo state neural network model for light propagation through strong atmospheric turbulence [11740-15]

$11740 \mathrm{OH} \quad$ Analyzing the impact of vibration on YOLO algorithm performance [11740-16]

$11740 \mathrm{Ol} \quad$ Enhanced computational imaging with encoding masks optimized by deep neural networks [11740-17]

11740 0J Ground-level temperature-emissivity-based contrast enhancement with uncooled multiband LWIR cameras [11740-18]

11740 OK Evaluation of augmented training datasets [11740-19]

$11740 \mathrm{ON}$ A machine learning approach to improving quality of atmospheric turbulence simulation [11740-22] 
$11740 \mathrm{OP} \quad$ Towards development of improved metrics for quantifying turbulence imposed degradation of long-range video [11740-24]

11740 OT The representation of complex image processing functions in EO/IR sensor system models and simulations [11740-35]

WINDOWS AND DOMES

11740 OW Performance verification of sun blocking filter for satellite based laser communication terminals [11740-29]

11740 OY Temperature dependent spectral line shifts in crystalline and polycrystalline materials [11740-31]

$117400 Z$ Development of near-net dome shaped ZnS window for the infrared region using Spark Plasma Sintering technique [11740-32]

1174010 Thermal shock resistance test on ZnS domes [11740-33] 